\title{
Tüketici Davranışına Göre Müşteri Sadakat Programı Algısının İlişkisel Pazarlama Kapsamında İncelenmesi
}

\author{
Ömer Sarı ${ }^{1}$ \\ Dr. Öğr. Üyesi Halime Göktaş Kulualp ${ }^{2 *}$
}

Geliş tarihi: 03.05.2019

Kabul tarihi: 05.07.2019

\section{Atıf bilgisi: \\ IBAD Sosyal Bilimler}

Dergisi (IBAD)

Sayı: 5

Sayfa: $48-69$

Yıl: 2019

Dönem: Güz

This article was checked by Turnitin. Similarity Index $02 \%$

\footnotetext{
1 Karabük Üniversitesi, Sosyal Bilimler Enstitüsü, omersarii0680@gmail.com, ORCID ID 0000-0002-7611-2362

${ }^{2}$ Karabük Üniversitesi, Safranbolu Turizm Fakültesi,

halimegoktas@karabuk.edu.tr ORCID ID 0000-0002-1485-3026
}

* Sorumlu yazar
ÖZ

Gelișen teknoloji, üretim ve tüketim döngüsü incelendiğinde yirminci yüzyılın sonlarına doğru müşteri odaklı bir yaklaşım benimsendiği görülmektedir. Bu süreçte müşterilerin beklenti, istek ve ihtiyaçlarını tatmin etmek önemli hale gelmiştir. Ancak sektörlerde ve sadık müşterinin yanı sıra yeni müşteri kazanmanın daha maliyetli olması ve mal/hizmetlerde yaşanan taklitler yeni uygulamaları zorunlu hale getirmiştir. Müşterilerin satın alma davranışlarını incelemek, kayıt etmek ve depolamak amacıyla micro-cip işlemciye sahip sadakat kartları ile sadık müşteri yaratma eğilimine girdikleri görülmektedir. İlk olarak hava yolları firmaları tarafindan daha sonraki sürçte ise hemen hemen her alanda popüler olan sadakat kartı uygulamaları ortaya çıkmıştır. İrili ufaklı birçok mal ve hizmeti bir arada satan perakende firmaları müşterilerini elde tutmak, tutundurma maliyetlerini azaltmak amacıyla sadakat kartı uygulamalarına başladıkları görülmektedir. $\mathrm{Bu}$ amaçla araştırma bir perakendeci firmanın sadakat kart uygulamasına sahip müşterileri üzerinde yapılmıştır. Elde edilen veriler bilgisayarlı ortamda analize tabi tutulmuștur.

Anahtar Kelimeler: Perakendecilik, İlişkisel Pazarlama, Sadakat Kartı, Müşteri Sadakat Programı, Alg1. 


\title{
Investigation of The Perception of The Customer Loyalty Program on Related Marketing
}

\author{
Ömer Sari ${ }^{*}$ \\ Dr. Lec. Halime Göktaş Kulualp**
}

First received: 03.05.2019

Accepted: 05.07.2019

\section{Citation:}

IBAD Journal of Social

Sciences (IBAD)

Issue: 5 Pages: 48-69

Year: 2019 Session: Fall

This article was checked by Turnitin. Similarity Index $02 \%$

1 Karabük Üniversitesi, Sosyal Bilimler Enstitüsü, omersarii0680@gmail.com, ORCID ID 0000-0002-7611-2362

2 Karabük Üniversitesi, Safranbolu Turizm Fakültesi,

halimegoktas@karabuk.edu.tr

ORCID ID 0000-0002-1485-3026

* Corresponding Author

\begin{abstract}
When the developing technology, production and consumption cycle is examined, it is seen that a customer-oriented approach towards the end of the twentieth century has been adopted. In this process, it has become important to satisfy the expectations, demands and needs of the customers. However, in the sectors and loyal customers as well as being more costly to acquire new customers and imitations in goods / services have made new applications mandatory. It is seen that customers tend to create loyal customers with loyalty cards that have micro-cip processors to examine, record and store their purchasing behaviors. Initially, the loyalty card applications, which are popular in almost every field, have emerged by the airline companies in the future. It is seen that retail companies that sell many goods and services together and start loyalty card applications in order to keep their customers and decrease their promotion costs. For this purpose, research has been done on customers who have a loyalty card application of a retailer company. The data were analyzed in computerized environment.
\end{abstract}

Keywords: Retail, Relational Marketing, Loyalty Card, Customer Loyalty Program, Perception. 


\section{KAVRAMSAL ÇERÇEVE 1.1. ILIŞKISEL PAZARLAMA}

Sürekli olarak değişen teknoloji, rekabet koşullarında da değişikliği beraberinde getirmiştir. İşletmeler, müşterilerinin istek ve/veya ihtiyaçlarını karşılayacak ürün üretmenin rekabet avantajına olan etkisine ek olarak işletmelerin bireysel anlamda ki gereksinimlerini tatmin edici davranışlar sergileyerek müşteri ile uzun dönemli ilişkiler kurması gerekmektedir. Ayrıca işletmeler için yeni müşteri kazanmanın aksine mevcut müşterileri ile uzun dönemli ilişkiler kurması karlı ilişlerin artmasını sağlayacaktır (Pirtini, 2010, s. 64; Aktepe vd., 2009, s. 26-27).

Yirminci yüzyılın son dönemlerinde önemli tartışma konusu haline gelen "ilişkisel pazarlama" terimi her geçen gün önem kazanmaktadır. Özellikle araştırmacılar tarafından sıklıkla tartışılan ilişkisel pazarlamanın, işletmeler için ne tür bir öneme sahip olduğu vurgulanmaya çalışılmıştır. Bu pazarlama modeliyle işletmeler, müş̧eriyi sürekli kılmak ve memnuniyet düzeylerini belirleyerek tatmin duygusunu yükseltmeyi amaç edinmişlerdir (Egan, 2004, s. 3; Yükselen, 2013, s. 38). Araştırmacılar ise ilişkisel pazarlama kavramını açıklığa kavuşturmak için aşağıdaki sorulara cevap aramışlardır (Brennan vd., 2003, s. 129):

- Uzun dönemli alıcı ve satıcı ilişkilerinin kesin olarak ne olduğunun incelenerek bu ilişkinin hayat döngüsü kavramının nasıl inceleneceği?

- İlişkisel pazarlamadan kastedilen şeyin ne olduğu ve bu kavramın nasıl tanımlanması gerektiği?

- I İlişkisel pazarlamanın uygulaması nasıl olmalıdır ve pazarın doğasına nasıl uyum sağlanmalıdır (hizmet ve/veya mal üreten sektörler için)?

- Pazarlamadaki bu yeni yaklaşım ile ilgili ne gibi zorlukların olabileceği ve/veya ortaya çıkabileceği?

Bu bağlamda perakendecilik sektörü ile ilgili olarak bir tanım yapan Berman ve Evans (2004, s. 15)'e göre; perakende işletmelerinde müşterileri işletmeye çekerek ilişkilerin sürdürülmesi şeklinde yeni müşteri elde etmekten daha çok elde edilen müşteriler ile ilişkilerin sürdürülmesi şeklinde ifade etmektedir. Benzer şekilde tanım yapan Tek (2005, s. 20-21)'e göre ise, "ilişkisel pazarlama müşteri odakl yaklaşımın ve modern pazarlama felsefesinin önemli araçlarından biridir" ifadesi ile müşteri tatmini ve uzun süreli müşteri ilişkisine vurgu yaparak ilişkisel pazarlamanın fonksiyonlarından bahsetmektedir. Ayıca karşılıklı değer yaratan ve işletme paydaşlarından olan müşteri ile ilişkilerini yeniden başlatan pekiştiren ve dengeleyici bir yaklaşım sergileyen ilişkisel pazarlama; paydaş uyumu, karar uyumu, bölge-zaman uyumunu ve değer uyumunu vurgulamaktadır. İlişkisel pazarlamanın tanımından zaman içerisinde farklı fonksiyonel özelliklerinde değişiklik yapılarak kavramın gelişimi gözlenmektedir (Bruhn, 2003, s. 11; Varinli, 2008, s. 95).

Post modern akımlardan biri olarak değerlendirilen ilişkisel pazarlama kavramı, iş ilişkilerinin güvene dayalı ve ticari boyuta ek olarak duygusal boyutu da içerisinde barındırarak müşterilerin isteklerini gerçekleştirmeye yönelik uzun vadeli ilişkiler kurmaya devam ettirme-geliştirme evrelerinden oluşmaktadır. Gelişen yeni akımlar ile pazarlama; "yüksek değerli müssterilerle güvene dayalı ilişkiler kuracak ve sürekli farkl olma üstünlügü yaratacak stratejiler gelisstirip yürütmek suretiyle hissedar kazancını çoğaltmaya çalışan yönetim sürecidir" olarak tanımlamaya başlamıştır (Doyle, 2003, s. 141).

Tüm bunlara ilave olarak müşterilerin işletme için ve daha geniş yığınlara ulaşarak olumlu bir marka imajı yaratılması gibi unsurlar, öncelikli olarak üretim sürecinde insan faktörünün çok fazla olduğu hizmet sektörlerinde daha sonra da diğer mal üreten sektörlerde ürünün pazarlama aşamasında ilişkisel pazarlama yaklaşımının benimsenmesini zorunlu hale getirmektedir. İşletmeler bu yeni yaklaşım kapsamında stratejilerini oluştururken müşteri sadakatinin temel unsurlarını ve bu unsurlara uygun sadakat programları geliştirmektedir. Böylelikle müşteri değeri, marka imajı, müşteri memnuniyeti ve müşteri bağlllığ bu yeni pazarlama stratejisinin temel bileşenlerini oluşturmuştur. Bu durum müşteri boyutunda ise müşterilerin işletmeden geçmişteki satın alma deneyimlerini kullanarak ilişkisel süreci belirleme konusunda etkili olacaktır. İşletmenin makro anlamda ilişkiye yaptığı yatırımlar arttıkça ve karşılıklı iletişim istenilen seviyede, uzadıkça ise müş̧erinin bu ilişkiden elde ettiği tatmin, duyduğu güven, sadakat ve ilişkiyi sürdürme kararlılığı artmaktadır. Mikro anlamda ise işletme kendi pazarlama yelpazesini genişletecektir. Bu durumun aksine işletmenin bu iletişim sürecini fırsatçı ve güvensiz bir 
yaklaşım sergilemesinde müşteri-işletme ilişkisini sonlandırması ile sonuçlandığı görülmektedir (Aydın, 2014, s. 67-68; Kılıç, 2010, s. 150; Christopher vd., 1991, s. 7; Marina vd., 2016, s. 49).

\subsection{MÜŞTERI SADAKATI KAVRAMI}

İlişkisel pazarlama modelinin oluşumunda önemli boyutu olan sadakat kavramı, müşteri ve işletme ilişkisinin kurulması ve sürdürülmesinde temel modül görevini oluşturmaktadır. Sadakat kavramı, içten bağlllık, sağlam, samimi ve güçlü dostluk ilişkilerini temsil eden kelime olarak nitelendirilmektedir. Müssteri sadakati ise Altıntaş $(2000$, s. 29) tarafindan "gelecekte daha önceden bilinen veya tavsiye edilen mal/hizmeti yeniden satın alma veya yeniden satın alma eğilimine yoğun biçimde yönelmesi ve katılmasıdır" olarak ifade edilmiştir. Daha basit haliyle bir müşterinin bir işletmeye sadık olarak uzun ilişkiler kurması ve sürdürmesi olarak tanımlanabilir. Tanımlamalara bakıldığında müşteri sadakati ile marka sadakati kavramları benzer özellikler göstermektedir. İşletmenin geçmiş dönemlerde, müşterilerine yönelik davranışları ile gelecek dönemde oluşacak bağlılığın temellerini oluşturacaktır ya da bitirecektir. İşletmeler, oluşan sadakat kavramı ile müşteriyi elde tutma ve uzun ilişsiler kurarak kar marjını arttırmayı sağlama amacı olduğu görülmektedir (Çakır ve Eğinli, 2010, s. 106-107; Doyle, 2003, s. 157; TDK, 2018).

Sadık bir müşteri profili aşağıda yer alan davranışları sergilemekte veya sergileme eğiliminde bulunmaktadır. Bu amaçla sadık müşteri (Erk, 2009, s. 44-45)

- Düzenli olarak bir işyerinden alışveriş yapan,

- $\quad$ Aynı iş yerinden birçok ürün (çarpraz ürün) ya da hizmet alan,

- $\quad$ Alışveriş yaptığı mağazayı diğer müşterilere tavsiye eden,

- Rekabetin tüm çekiciliğine rağmen şirkete olan bağlılığını gösteren müşteridir.

Giderek yoğunlaşan rekabet şartları işletmeleri geleneksel yöntemlerden arındırarak farklılaşmaya itmektedir. Bu farklılığı oluşturmak için hizmet/mal üreten tüm sektörler kalıcı müşteri veya uzun vadeli ilişkiler kuracağı müşteriler elde ederek karlılı̆ıının devamını sağlamak için sadakat programları oluşturmaya başlamaktadır. Sadakat programları ile müşterilerini ödüllendirerek bu ilişki ve/veya iletişimi kalıcı hale getirmek temel amaçlar olarak nitelendirilmektedir. İşletmeler sadakat programlarını pazarlama silahı olarak tanımlayarak strateji oluştururken bu bilinç ile oluşturmayı hedeflemektedir. Aksi takdirde kısa dönemli bir iletişim sorunu ve/veya maliyetleri de beraberinde getirecektir. Dolayısıyla müşteriye aidiyet duygusunu yaşatacak bir bağlılık oluşturmak zorunlu hale gelmektedir (Oyman, 2002, s. 184).

Müşteri sadakatinin belirleyici birçok unsur bulunmaktadır. Ancak müşteri değeri ve tatmini bunların başında gelmektedir. Müş̧eri tatmini sağlayan işletmelerde sadakat müşteri profili oluştuğu görülmektedir. Bu durum işletmelerin reklam ve tutundurma alanında fayda sağladığı düşünülmektedir. Dolayısıyla işletmelerin maliyetten kazanç sağlamasına katkı sağlamaktadır. Böylelikle işletmenin maliyetten elde ettiği kazanç müşterilerine bir değer olarak dönecektir. İşletme müşterilerine vermiş olduğu değerle onları elde tutarak uzun ilişkiler sağlayacaktır. Benzer şekilde satılan mal/hizmetin müşteriye vaat edilen ihtiyacın karşılanması temel olarak görülse de günümüz dünyasında önemli yer edinmiş olan; enerji tasarrufu, doğal çevre verdiği zarar, ekoloji etkisi, insan sağlığına zarar vb. gibi değişkenler müşteri memnuniyetinin oluşmasına katkı sağlamaktadır $\mathrm{Bu}$ durum müşteri odaklı düşüncenin vazgeçilmez unsurları haline gelmiştir (Alabay, 2008, s. 40-41; Ünal, 2013, s. 1-2).

İşletmeler mevcut müşterileri korumak, karlılığını artırmak ve işletme/marka sadakatini oluşturmak için sadakat programları oluşturmaktadır. Müşterinin mal/hizmeti tekrar satın almasını sağlayacak teşvik edici sisteme denilmektedir. Ayrıca müşterilerin en az risk ve en fazla güven ile aynı işletmeden sık sık mal/hizmet satın almasına olanak sağlamaktadır. Özellikle hizmet sektöründe müşteri; satın almadan önce algılanan riski ve bilgi eksikliğini en az seviyeye çekmeye çalışmak amacıyla psikolojik katılım sağlar. Daha sonraki süreçte ise işletme ve müşteri karşlıklı olarak güvene dayalı ilişkiler geliştirmektedirler. Sadakatin ayrılmaz bir parçası olan güvenin tam ve doğru şekilde oluşup kullanılması halinde kişisel etkileşim kaçınılmaz olacaktır (Demirel, 2007, s. 132,183; Anderson ve Vincze, 2004, s. $310)$. 


\subsection{SADAKAT ÇEŞITLERI VE DÜZEYLERI}

Müşteri sadakat kavramı bir süreci kapsamaktadır. Bazı müşteriler başlangıç aşamasındayken bazıları ise daha ileriki aşamalarda olabilir bu nedenle müşteri sadakati geliştirmenin, mevcut olduğu yerde müşteri katılımından yararlanmalıdır. $\mathrm{Bu}$ durum, satın alma davranışlarındaki tercihlere ve psikolojik değerlendirmelere dayanan tercihler oluşmasına firsat tanıyacaktır. Birçok işletme, müşteri gruplarını veya tutum ve motivasyonları, satın alma stilleri ve satın alma stratejilerine göre sadakat düzeylerine göre sinıflandırarak strateji geliştirebilir (Knox, 1998, s. 732).

Hollensen'e (2003, s. 618-620) göre sadakat düzeyleri şu şekildedir:

- Sadakatsizlik: $\mathrm{Bu}$ düzeyde tüketicilerin satın alma davranışı olmadığı gibi çok nadiren de olabilir.

- Sahte sadakat: Alternatiflerin çok farklı olduğu durumlarda müşterinin satın alma davranışı gerçekleşse dahi sadakat olarak görülmemektedir. Bu durum tamamen geçicidir ancak işletme yöneticileri bu durumu sadakat programlarından müşteriyi ödüllendirici vb. uygulamalar ile geçicilikten kurtararak müş̧eri sadakatine dönüştürebilirler.

- Gizli sadakat: Müşterilerin sektörde bulunan işletmeye ya da markaya olan tutumları vardır ancak bu durumu ispat edebilecek somut olarak satın alma davranışına ilişkin kanıt bulunmamaktadır. $\mathrm{Bu}$ duruma neden olarak; uygun olmayan mağaza konumu ve stok durumu vb. say1labilmektedir.

- Sadakat: Sadakatin tam olarak oluşması ile müşteri aynı işletme ile düzenli olarak satın alma işlemini tekrarlamaktadır. Böylelikle müşteri fiyat avantajından müş̧eriye değer veren ek hizmetlerden ve firsatlardan yararlanabilmektedir.

- Sadakat çeşitleri literatürde farklı kişiler tarafindan farklı olarak kategorize edilmektedir. Altıntaş'a göre müşteri sadakat türleri aşağıdaki gibidir (Altıntaş, 2000, s. 31-32):

- Bilişsel sadakat: sadakatin ilk aşamasında yer alan ve geçmiş dönemlerdeki deneyimlere bağlı olarak kazanılan bilgiden dolayı belirli bir markaya yönelme işini oluşturmaktadır. Böylelikle marka inancına bağlı bir sadakat türünü oluşturur.

- Duygusal sadakat: sadakatin ikinci aşamasın bilişselden sonra gelen duygusal sadakat müşterinin geçmiş dönemlerindeki kazanılan memnuniyet ile işletme müşteri arasında duygusal bir bağ kurmayı amaç edinir.

- Davranışsal eğilimli sadakat: sadakatin davranışsal boyutunu temsil etmektedir. Bu aşama da müşteri bilişsel ve duygusal sadakatin arkasından satın alma davranışını yineleyerek müşteri sadakati elde edilmektedir.

- Doğrudan davranışa yönelik sadakat: bu aşamaya kadar ki süreçlerde müşteri eyleme geçme hazırlığı içerisindedir. Ancak bu süreç de sadakat doğrudan eyleme hazırdır. Böylelikle satın alma davranışının tekrarlı olarak devam etmesi beklenmektedir.

- Butscher' e (2002, s. 6-7) göre ise müşteri sadakat programları sınırlı sadakat programları ve açık sadakat programları olmak üzere iki grupta sınıflandırılabilir.

- Açık sadakat programlarının giriş koşulları yoktur. Bir giriş koşulunun olmaması üyeliği daha çok insan için daha cazip ve daha kolay hale getirecektir. Ancak çoğu zaman şirketten fayda sağlamayan birçok üye bulunabilir. Çok geniş hedef grupları tanımlanmışsa veya potansiyel ve rakip müşterileri de birincil hedef gruplar ise idealdirler.

- Sınırlı sadakat programları ise; üyeliğe hak kazanabilmek için bazı kriterler yerine getirilmesini şart koşmakta ancak çoğunlukla bir üyelik ücreti ile tamamlanmış bir başvuru formunu da zorunlu tutmaktadır.

\subsection{MÜŞTERI SADAKAT PROGRAMLARI}

1990'larda popüler olarak büyüyen eğilimlerin içerisinde olan sadakat programları daha çok büyük havayolu şirketleri tarafından sıklıkla kullanılmaya başlanmıştır. Günümüzde hemen hemen her işletme marka sadakati oluşturmak, kalıcı müşteri kitlesi yaratmak ve elde tutmak, kar marjını arttırmak vb. gibi sebeplerden dolayı müşteri sadakat programları kullanmaktadırlar. Mevcut müssterilerin bir işletmeye olan müşteri sadakati ile o işletmenin sitesini veya ürünlerini arkadaşlarına, dostlarına ve tanıdıklarına tavsiye ederek yeni müşteri elde edebilmektedir. Bu programlar müşteri ödüllendirmeye ve satın alma davranış sıklıklarını arttırmaya yönelik amaçlar taşımaktadır (Winer, 2007, s. 414; Ünal, 2013, s. 10; Hollensen, 2003, s. 599; Akın Acuner, 2004, s. 66-69). 
Sadakat programları araştırmacılar tarafından farklı bakış açıları ile değerlendirilmektedir. $\mathrm{Bu}$ programlar Akın Acuner'e (2004) göre:

- Sürekli müşterilere sağlanan ayrıcalıklar programı,

- Sürekli müşteri gönde4renler için programlar,

- Teşekkür kartları,

- $\quad$ Şirket gazetesi veya kişisel mektuplar,

- Telefonla hatırlatma,

- Müşterinin katkısını bilmek ve ödüllendirme programları,

- Müşteriye özel olaylar,

- Stratejik birliktelikler ve ortaklıklar olarak yorumlanmıştır.

- Ünal'a (2013) göre ise:

- Hizmet alımı için antlaşma yapma ve yenileme karşılığında bedava hediyeler verme,

- Hizmet alım sözleşmelerini yenilemeleri hainde müşterinin indirim kazanmalarını sağlayacak düzenlemeler yapma,

- $\quad$ İlişkili şirketlerde ürün alan müşterileri ödüllendirme,

- Başka şirketler tarafından indirimli ürünler sağlayarak puanlama sistemi ile ödüllendirecek karmaşık sistemler oluşturma olarak açıklanmaktadır.

\subsection{SADAKAT KARTI UYGULAMASI}

Değişen teknoloji ile müşteri sadakatini artırmak için içerisinde özel amaçları barındıran üyelik kartları oluşturulmaya başlanmıştır. Bu kartlarda, içerisindeki mikro-işlemciler ve arka yüzündeki manyetik şerit sayesinde müşterilerin satın alma davranışlarını bilgilendirme sistemlerine ileterek depolamaktadır. Elde edilen veriler sayesinde müşterinin indirim puanı, hediye, sinema bileti vb. gibi ödüllendirme sistemleriyle işletmeye olan sadakat bağının artması beklenmektedir. Örneğin İngiltere'deki Shell istasyonunda müşterilerin toplayacağ 1 puanlarla sinema bileti, uçuş bileti ve çeşitli hediyeler vaat edilerek müşseri sadakatinin oluşması ve satın alma davranışının arttırılması beklenmiştir (Winer, 2007, s. 414).

Hemen her sektörde uygulamalarına rastlanılan sadakat kartları perakende sektöründeki işletmeleri de yeni pazarlama yaklaşımlarını benimsemeye itmiștir. Bilgisayarlı teknoloji ile müşterilerin satın alma davranışlarındaki beklentiler perakendeci işletmeleri için çok önemli bir konu haline gelmektedir. Bu tür işletmelerin ürünler üzerindeki indirim ve ödüllere ek olarak müşteri ilişkileri uygulamalarına (CRM) imkân tanıyarak perakendeciliği daha da üstün bir seviye taşınmasına izin verecektir. Bu durum müşteriler içinde; kartın rengi, kart sahibi mağazanın eve olan yakınlığı, kartın imajı, kartın sağladığ1 diğer olanaklar gibi tercih edilme değişkenlerine sebep olacak boyutta olmasıdır (Çabuk vd., 2006, s. 9293).

İşletmeler içerisinde mikro-işlemciler bulunan ve arka yüzündeki manyetik şeritli sadakat kartları sayesinde her müşterinin bireysel olarak verilerine ulaşmak ve bu verileri bilgiye döndürmek gibi firsatlar sunmaktadır. Müşterinin hangi ürünü ne zaman hangi sıklıkta satın aldığını bilgisayarlı depolama sisteminden görerek müşteri ile sağlıklı bir ilişkinin temelini de oluşturacak olan ilişkiler ve stratejiler geliştirebilmektedir (Kulabaş ve Sezgin, 2003, s. 78).

Sadakat kartları müşteri satın alma ve mağaza tercihlerinde etkili bir kanal olduğu gibi müşteriler ile ilişki kurma ve sürdürme eğilimine katkı sağlayan bir yöntem olmuştur. Özellikle bu kartların alışveriş sonunda müşteriye somut yarar sağlayacak ödüller ile fonksiyonel olması müşterinin satın alma kararlarında, mağaza tercihlerinde, sadakat kartı üye sayısı gibi değişkenlerin oluşmasında olumlu etkiler oluşabilmektedir (Göksel ve K1lıç, 2004, s. 162).

\subsection{PERAKENDECILIK KAVRAMI}

Dünya tarihinde makineleşme ve standartlaşma ile başlayan yığın üretim kendine özgü sorunları beraberinde getirmiştir. Bu sorunlardan en temeli, üretilen ürünlerin tüketiciye ulaştırılmasıdır. İşin bu noktasında pazarlama bileşenlerinden olan "dağıtım" bu görevi üstlenerek toplum tarafindan bilinen perakendecilik kavramını oluşturmuştur. Perakende kavramı, bir toplumdaki pazarlama, dağıtım ve ekonomik etkinliklerin tüketiciler tarafindan görünen yüzüdür. Kısacası hemen hemen her sektördeki ürünlerden küçük parçalar halinde tüketiciye yapılan satışlara denilmektedir. Bu nedenle perakendecilik 
sektörünün odağında müşterinin istek ve ihtiyaçları bulunmaktadır. Dünya da olduğu gibi Türkiye'de de her geçen gün büyük bir gelişme potansiyeli göstermekte ve gelişen teknoloji ile sürekli büyüyen bir sektör haline gelmektedir. Ancak perakendecilik sektöründe her sektörde olduğu gibi yoğun bir rekabet ortamı bulunmaktadır. Bu rekabet ortamında; kalitenin, ürün çeşidinin, fiyatın, ürün satış yerinin ve sergilenme şeklinin ve en önemlisi güvenilir olması talebin artmasına ve istenilen başarıya ulaşma anlamına gelmektedir (MEGEP, 2008, s. 3-4; Altunışık vd., 2012; Tek, 1997, s. 582).

Türkiye de 1990 yıllarını "perakendecilik çağı" olarak ifade etmek perakendecilik sektörünün daha da yükselişine olanak sağlamıştır. Uluslararası anlamda ise Amerika ve Avrupa Devletlerinde çok daha önceleri kitlesel perakendecilik sektörüne başlanmıştır. Günümüzde ise teknoloji ve değişen çevrenin de etkisiyle uzmanlaşmış büyük mağazalar halinde karşımıza çıktığı görülmektedir. Ürünlerin nerede ve nasıl satıldığının bir önemi yoktur. Çağdaş perakendecilik düşük kar marjı ve yükssek stok devir hızı ile kitlesel olarak büyümeye devam etmektedir. Buna ek olarak modern anlamda perakendecilik mal ve hizmeti yan yana sunarak işlevini genişletmiştir. Bu anlamda, modern pazarlamanın özellikleri; yetişmiş personel, profesyonel yönetim anlayışı, büyük ölçekli olma vb. gibi uzmanlaşmış bir kuruluşun özelliklerini yansıtmaktadır. Bunlara; süpermarketler, hipermarketler, zincir mağazalar ve alışveriş merkezleri örnek olarak sıralamak mümkün olacaktır (Altunışık vd., 2012; Kotler ve Keller, 2006, s. 504; Tek, 1997, s. 582-583).

\section{a) Perakendeciliğin Fonksiyonları}

Perakendecilik tüketicilere ürünleri satın alabileceği ve/veya tüketebileceği mekanda sunulmasını sağlamaktadır. Ayrıca perakendecilik nihai tüketiciler için biçim faydası, mekan faydası, bilgilenme faydası, mülkiyet faydası ve zaman faydası sağlayarak fonksiyonlarını arttırmaktadır. Böylelikle nihai tüketicilerin istediği ürünleri sunabilmek için malın yanında hizmet de sunmaktadırlar. Perakendecilik hedef pazarda uzun dönem müşteri istek ve ihtiyaçlarının yanı sıra müşterilerine sundukları hizmetten memnun etmeyi de amaçlamaktadır. Böylelikle yöneticiler müşteri merkezli ve değer odaklı olarak strateji geliştirebilir ve uygulamalarının devamlılı̆̆ını sağlayabilirler. Perakende kavramı; müşteri odaklı (customer orientation), aktivitelerin koordinasyonu (coordinated effort), değer odaklı (valu-driven) ve hedef odaklı (goal orientation) olarak dört prensipten oluşarak stratejileri belirlenmektedir. Aşağıdaki şekilde perakende kavramı şemasında gösterilmiştir (Altunışık vd., 2012, s. 282; Berman ve Evans, 2004, s. 12; Oluç, 2006, s. 366).

\section{Şekil 1: Perakende Kavramı Şeması}

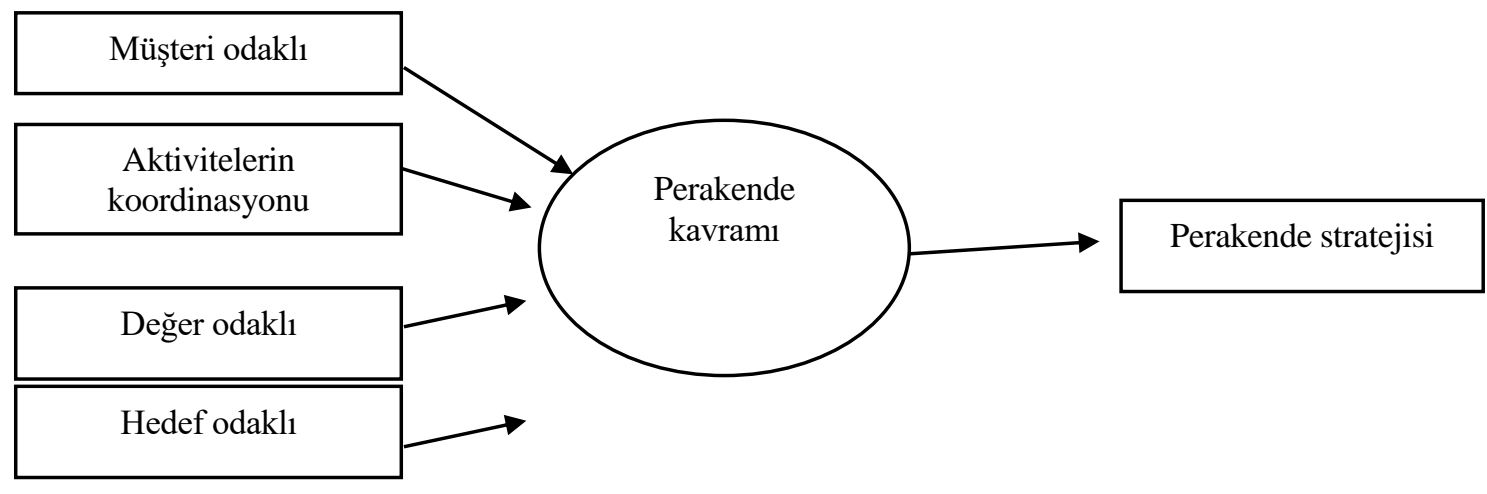

Kaynak: Berman ve Evans, 2004, s. 12

Bu kavram şemasına göre:

- Perakendeci, müşterilerinin ihtiyaçlarını belirler ve bu ihtiyaçları en üst düzeyde karşılamak için gayret gösterir,

- Perakendeci verimliliği en üst düzeye çıkarmak için tüm plan ve etkinlikleri bütünleştirir,

- Perakendeci müşterilere hem pahalı hem de indirimli ürün ve müşteri hizmetleri sunarak müşterilerine iyi değer sunar ve

- $\quad$ Perakendeci hedef belirler ve ona ulaşmak için stratejisini kullanır 
şeklinde tanımlanabilir (Berman ve Evans, 2004, s. 12-13).

\section{b) Perakendeci Çeşitleri}

Perakendeci türleri de yaşam döngüsü olarak tabir edilen bir döngüye sahiptir bu döngüye göre bir perakendeci tipi ortaya çıkar hızlı büyüme safhalarını tamamlayarak olgunluğa erişir ve bir süre olgunluğu yaşadıktan sonra son olarak gerilemeye başlamaktadırlar (Kotler, 2000, s. 520).

Perakende halkasının son teorisine göre geleneksel perakende mağazalar genellikle maliyetlerini karşılamak için hizmetlerini ve fiyatlarını artırarak daha düşük fiyat daha az hizmet sunan ve spesifik hizmetlerle çok farklı tüketicilere hizmet sunan yeni mağaza şekilleri oluşmaktadır. Kimi perakendeciler gösterişli semtlerde kimileri ise küçük semtlerde yer alarak farklı özelliklerine göre sınıflandırılmaktadır. Perakendeci türleri; yerleşime göre, mülkiyete göre, verilen hizmete göre ve satılan mallara göre aşağıdaki tablo da sinıflandırılmıştır (Altunışık vd., 2012, s. 291; Kotler ve Keller, 2006, s. 504; Oluç, 2006, s. 369).

\section{Tablo 1: Perakendecilik Sınıflandırması}

\begin{tabular}{|c|c|c|}
\hline Sinıflandırma Kriteri & & Perakendeci İsmi \\
\hline \multirow[t]{4}{*}{ Satılan mallara göre } & $\bullet$ & Her türlü tüketim malı satanlar \\
\hline & & Kolaylık mağazaları \\
\hline & - & Departmanlı mağazalar \\
\hline & $\bullet$ & Çeşit mağazaları \\
\hline \multirow[t]{5}{*}{ Verilen hizmetlere göre } & $\bullet$ & Hizmet mağazaları self servis mağazaları \\
\hline & & Öde götür mağazaları süper marketler \\
\hline & $\bullet$ & Mağazasız perakendecilik \\
\hline & $\bullet$ & Doğrudan pazarlama doğrudan satış \\
\hline & $\bullet$ & Otomatik makineli satışlar \\
\hline \multirow[t]{4}{*}{ Mülkiyete göre } & 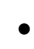 & Bağımsız perakendeciler kamu mağazaları \\
\hline & & Perakendeci gruplaşmaları \\
\hline & $\bullet$ & Koperatif mağazaları \\
\hline & $\bullet$ & Franchising mağazaları kiralanmış reyonlar \\
\hline \multirow[t]{4}{*}{ Yerleşime göre } & $\bullet$ & Mahalledeki perakendeciler \\
\hline & $\bullet$ & Semt pazarındaki satıcılar \\
\hline & $\bullet$ & Benzin istasyonundaki satıcılar \\
\hline & $\bullet$ & İssportacılar \\
\hline
\end{tabular}

Kaynak: Altunışık vd., 2012, s. 291.

Departmanlı Mağaza: Mağaza içinde satılan faklı ürünlerin reyonda bulunmuş olmasına ve reyonların bir kısmı ve/veya tamamı bir işletmeye kiralanarak kazanç elde edilen tek veya çok katlı mağazalardır. Mağazanın büyük olması stok devrinin yüksek olması ile düşük kar oranı ile kazanç elde edilen "mağaza" türüne denir (Altunışık vd., 2012, s. 291). Departmanlı mağazaların literatürde ki tanımlarına istinaden şu özelliklerinin içerisinde bulundurması gerekmektedir (İslamoğlu, 2006, s. 370);

- Satıs yönteminin self-servis olmasl

- $\quad$ Farkl fonksiyonel özelliği olan beğenmeli malların farkl bölümlerin de yer alması

- $\quad$ Fiziksel anlamda mağazanin büyük hacim kapasitesinin olmasi gerekmektedir. 
Zincir Mağaza: Herhangi bir işletmenin benzer konuda faaliyet gösteren tutundurma faaliyetlerinin daha düşük maliyetlere sahip olduğu ve büyük oranda alınan ürünlerin satıldığı büyük mağazalara zincir mağaza denir (Altunışık vd., 2012, s. 291-292). Zincir mağazalar isminden de anlaşılacağ 1 gibi çoğu zaman aynı konsept de sahip süpermarketlerin oluşturduğu mağaza türüdür. Ancak içlerinden bazıları departmanlı büyük mağaza türleri olabilir. Zincir mağazalarda satın almalar mağazadan mağazaya değişebileceği gibi toplu olarak da yapılabilir hatta fiyat politikaları da benzer olarak mağazadan mağazaya değiştiği gibi merkezi fiyat politikası da uygulanabilir ancak en temel özellik satın alınan ürünlerin büyük oranlarda olması gerekir (İslamoğlu, 2006, s. 371).

Süpermarket: Daha çok temizlik gıda vb. ürünlerin self servis olarak satıldığ depolama sisteminin yüksek devrinden dolayı fiyatları düşük olan mağazalardır (Altunışık vd., 2012, s. 292). Ayrıca süpermarketler bulundukları coğrafyanın ekonomik yapısına büyüklüklerine göre farklılık gösterebilmektedir. Bu yüzden literatür de farklı tanımlara rastlamak mümkün olacaktır (İslamoğlu, 2006, s. 370).

Hipermarket: Giyim ve gıdaya ek olarak kuaför, masaj salonu ve otoparkı olan satı̧ ve fiziki hacim olarak süpermarketlerinde büyüğü olarak bilinen mağaza türüdür. En az $2500 \mathrm{~m}^{2}$ satış alanı ve otopark1 ile ortalama 8000-20.000 $\mathrm{m}^{2}$ arasında değişebilir. Ayrıca hipermarketler indirim ve depo mağazacılığının bir tür birleşmesi olarak nitelendirilebilir. Böylelikle hem indirim olanağı hem de stok devir hızını yüksek tutar (Tek, 1997, s. 592; Altunışık vd., 2012).

Alış Veriş Merkezi: Tek bölmeli bir plan altında küçük büyük perakendecilere yer kiralayarak ürün satmalarını sağlayan ilaveten içerisinde kuaför, sinema, kafe vb. gibi hizmetleri de sağlayan bir kompleks olarak bilinmektedir. Fiziki olarak satış alanları $5000 \mathrm{~m}^{2}$ başlayarak $80.000 \mathrm{~m}^{2}$ kadar çıkabilmektedir. Benzerlik olarak ülkemizde bulunan kapalı çarş1 modeline benzeyen bu kompleks Türkiye de ilk olarak 1976 yılında "efes shopping center" adında bir alış veriş merkezi kurulmuştur (Tek, 1997, s. 593).

Indirim Mağazaları: Adından anlaşılacağı üzere tüketicilere düşük fiyatlardan mal satmayı ve yüksek raf devir hızı ile kar elde etmeyi amaçlayan mağazalardır. Ortalama $1000 \mathrm{~m}^{2}$ satış alanına sahip ve tüketicilerine kaliteli ve/veya kalitesiz ürünler satarak hizmet vermektedir (Tek, 1997, s. 594; Altunışık vd., 2012).

\subsection{ILIŞKISEL PAZARLAMA VE MÜŞTERI SADAKATINE İLIŞKIN LITERATÜR TARAMASI}

Grönroos (1997) bir araştırmasında işletmelerin müşterileriyle uzun vadeli ilişkiler kurmasını kapsayan ilişkisel pazarlama üzerine yoğunlaşmıştır. Bir işletmenin, müşterilerinin uzun vadeli değer gereksinimlerini karşılamak için üründen daha fazla kaynak veya etkinlik sunmasının gerektiğini savunmaktadır. Araştırmada, işletmelerin değer odaklı yaklaşımı benimseyerek bir ilişsisel amaç benimsediğinde müşteri ile ilişkiyi sürdürme bağlamında başarılı olabileceği sonucunu elde etmiştir.

Sirdeshmukh ve Sabol (2002) bir araştırmasında ilişkisel pazarlama anlayışında tüketici güven, değer ve sadakat kriterleri üzerine yoğunlaşmaktadır. Müşteri güvenini veya işletme ilişkisel pazarlama anlayışına yönelik davranışlarını ve uygulamalarını müşteri güveni, değer ve sadakate dönüştüren çerçeveyi ortaya koymayı amaçlamıștır. Bu doğrultuda araştırmanın bulgusu müşteri güveni üzerinde bir çerçeve oluşturulmuştur. Bu çerçeve değer ve sadakat algısının ortaya konmasında kilit rol üstlendiği sonucu elde edilmiştir. İşletmelerin ilişkisel pazarlama anlayışına yönelik uygulama ve faaliyetlerinde güven faktörünü esas alan modellerin geliştirilmesi önerilmiştir.

Styles ve Ambler (2003) tarafından gerçekleştirilen bir araştırmada, Çin de yer alan firmaların ilişkisel pazarlama yaklaşımı benimsemeleri halinde ticari açıdan tutarlı bir davranış sergilediklerinin göstergesi olarak kabul edildiği yaklaşımını benimsemektedir. Bu durumun kaynă̆ı ise, küresel bir yapı haline gelen işletmelerin batıdaki ilişkisel pazarlama anlayışından etkilendiği saptanmıştır.

Kulabaş ve Sezgin (2003) bir araştırmasında ilişkisel pazarlama modeliyle müşteriyi geri döndürme kuvvetini incelemiştir. Bu modelde; ilişki kurma, teknoloji, organizasyonel değişim, kalite benzersizlik ve ahlak kriterleri göz önünde bulundurulmuştur. Bu kriterlerin İngilizce yazılışları esas alınarak baş harflerinden TORQUE modeli olarak isimlendirilmiştir. Bu doğrultuda elde edilen bulgular ilişkisel 
pazarlama anlayışının başarılı olabilmesi ilişki stratejisinin tanımlanmasından, kaliteye, karşılıklı güvenden, kişiselleştirilmiş hizmetlere kadar çoğu faktörün bulunabileceğinden dolayı işletmelerin örgüt yapısında değişimlere gitmeleri ve teknolojik altyapılarını güncel hale getirmeleri vurgulanmaktadır.

Hacıefendioğlu ve Çolular (2008) bir araştırmasında ilişkisel pazarlama anlayışında güven faktörü üzerine yoğunlaşmaktadır. Otel işletmelerinde müşteri güvenini etkileyen faktörler irdelenerek ilişkisel pazarlamadaki önemi vurgulanmaktadır. Bu doğrultuda, müşteri güvenini etkileyen faktörlere yönelik bulgular somut varlıklar, tavsiye edilebilirlik, güven aşılama, ambiyans, heveslilik ve empati olarak belirlenmiştir. $\mathrm{Bu}$ faktörlerin müşteri güvenindeki rolü \%71'ini açıkladığı sonucuna ulaşılmıştır. Dolayısıyla müşteri güven kriterlerinin ilişkisel pazarlama anlayışına katkı sağladığından dolayı müşteri güven boyutlarının belirlenmesi ve buna yönelik planların oluşturulması sonucu elde edilmiştir.

Çatı, Koçoğlu ve Gelibolu (2010), beş yıldızlı otel işletmelerinde müşteri beklentileri ile sadakati arasındaki ilişkiyi incelemiş ve 176 otel müşterisinden anket verisi toplamıştır. Analiz sonuçlarına göre, müşteri beklentilerinin boyutları; fiziki unsurlar, nezaket, güvenilirlik, empati, güven ve yeterlilik olarak tespit edilmiştir. Regresyon analizi bulgularına göre ise, beklenti boyutları ile tutumsal ve davranışsal sadakat boyutları arasında anlamlı bir ilişki tespit edilmiştir.

Özdemir ve Koçak (2012) tarafindan gerçekleştirilen bir araştırmada, öğrenciler üzerinde marka sadakatinin davranışsal ve tutumsal sadakati nasıl etkilediği irdelenmiş̧lerdir. Bu doğrultuda, mağazaya olan güven arttıkça tutumsal ve davranışsal sadakatin arttığı gözlenmiştir.

\section{METODOLOJI}

$\mathrm{Bu}$ araştırma, ilişkisel pazarlama kapsamında perakendeci mağazalar üzerinde sadakat kartlarının etkisini incelemeyi amaçlamaktadır. Kümeyi temsil edici alanların seçiminde, bir örneklemin seçilme sürecinde belirli bir yargı güdülmüşse gayeli örneklem tekniği kullanılmaktadır (Arıkan, 2013, s. 119). Bu amaçla, araştırmada gayeli örneklem tekniği kullanılarak seçilen perakende mağazalarının merkezi olan Ankara/Mamak ilçesi seçilmiştir. Geniş kitlelere uygulanarak üzerinde istatistik değerlendirmelerde bulunmak amacıyla belirli bir amaç ve plana göre hazırlanmış soru listesine anket ismi verilmektedir (Karasar, 2014, s. 176). Bu bağlamda araştırma üzerinde istatistiksel değerlendirmelerde bulunmak amacıyla anket tekniği ile incelenmiş̧ir.

Araştırma kapsamında yer anket sorular tablo 2 de yer alan çalışmalardan derlenmiştir. Soru maddelerinin yanıtları 5'li likert tipi olarak belirlenmiştir. Bu amaçla kullanılan ifadeler " $1=$ Kesinlikle Katılmiyorum, 2=Katılmıyorum, 3=Kararsızım, 4=Katılıyorum, 5=Kesinlikle Katıliyorum" şeklinde belirlenmiştir. Bu kapsamda 10 adet demografik ve 27 ölçek sorusu derlenmiş̧ir. Elde edilen veriler bilgisayarlı ortamda SPSS istatistik programında analizleri yapılmıştır.

Tablo 2: Araştırmada Kullanılan Ölçekler

\begin{tabular}{lll}
\hline Yazar & Kaynak & Ölçek Maddesine İlişkin Bölümler \\
\hline $\begin{array}{l}\text { East ve arkadaşları, } \\
2000\end{array}$ & First-store loyalty and retention & Sosyo-demografik değişenler \\
$\begin{array}{l}\text { Too ve arkadaşları, } \\
2001\end{array}$ & $\begin{array}{l}\text { Relationship marketing and customer loyalty } \\
\text { in a retail setting: a dyadic exploration }\end{array}$ & Sadakat programı algısı \\
Baloğlu, 2002 & $\begin{array}{l}\text { Dimensions of customer loyalty: Separating } \\
\text { friends from well wishers. }\end{array}$ & $\begin{array}{l}\text { Mağazaya olan güven } \\
\text { İlişkiyi sürdürme isteği }\end{array}$ \\
\hline
\end{tabular}

Araştırmaya katılan perakende mağaza kartları üyelerinin veri toplama aracındaki sorulara objektif ve samimi tutum sergiledikleri varsayılmaktadır. Bu araştırmanın verileri Ankara/Mamak'ta bulunan perakende mağaza kartları üyeleri ile sınırlıdır. Ayrıca araştırmanın verileri kişisel bilgi formu, sadakat programı algısı, mağazaya olan güven ve ilişkiyi sürdürme isteği tutumlarına ilişkin anket formu ile sinırlidır.

Araştırma kapsamında kullanılan ölçeklerin yapısal geçerliliği test etmek için açıklayıcı faktör analizi yapılmıştır. İlişkisel pazarlama uygulamalarının müşteri sadakati üzerinde etkili olduğu düşünülmektedir. Bu bağlamda müşterilerin sadakat programı algısı oldukça büyük öneme sahiptir (Too vd., 2001, s. 297). 
İlişkisel pazarlamanın en önemli değişkenlerinden biri olarak görülen güven faktörü sadakatin sürdürülebilir olmasında kritik bir değer olarak görülmektedir (Morgan ve Hunt, 1994, s. 31). Özellikle müşteriler ile ilişkiyi sürdürme isteği güven faktöründen kaynaklanmaktadır (Erten, 2004, s. 73). İlişkiyi sürdürme isteği sadakatin temsil edici bir davranış olduğunu nitelendirilmektedir. Bu açıdan, analiz sonunda elde edilen boyutlar sadakat programı algısı, mağazaya olan güven ve ilişkiyi sürdürme isteği olarak isimlendirilmiştir. Bu boyutlar üzerinde ortalama ve standart sapmaları alınarak Anova, t-testi ve Regresyon analizi ile yorumlanmıştır.

Ölçekte yer maddelerin homojenlik düzeyini belirlemek ve güvenilirliği test etmek için "Cronbach Alpha" analizi yapılmıştır. Bu bağlamda ölçeğin güvenilirliği 0,834 olarak çıkmıştır. Bu oran ölçek güvenilirliğinin literatürde genel kabul göreceğini göstermektedir (Kalayc1, 2010, s. 405).

\subsection{Araştırmanın Hipotezleri}

Morgan ve Hunt (1994)'a göre işletmelerde kurulan bağl1lığın sürdürülebilir olması, ilişkiyi sürdürme isteğinin devam etmesinde son derece önemli olduğunu vurgulamaktadır. Dolayısıyla mağazaya olan güvenin, ilişkiyi sürdürme isteğinin oluşumunda temel görevi üstlenmektedir. $\mathrm{Bu}$ doğrultuda $\mathrm{H}_{1}$ oluşturulmuştur.

\section{$H_{1}:$ Mağazaya olan güvenin ilişkiyi sürdürme isteği üzerinde etkisi vardır.}

Amine (1998), Dick ve Basu (1994) ve Ha (1998) araştırmalarında belirli bir markaya olan olumlu tutumun istikrarlı biçimde satın alma davranışına yansıması olarak ifade etmektedir. Marka sadakatinin oluşum evresi incelendiğinde markaya olan güvenin en temel belirleyici kriter olarak nitelendirildiği vurgulanmaktadır. Dolayısıyla mağazaya olan güven algısı sadakatin düzeyini ortaya koymada belirleyici rol oynadığı görülmektedir. Mağazaların oluşturduğu sadakat programları da benzer şekilde sadakatin oluşum evresinde yer alan güven faktörü göz önüne alınmasının zorunlu olabileceği vurgulanmaktadır. Ballester ve Alemán (2005) tarafından yapılan çalışmada marka sadakatinin belirlenmesinde markaya olan güven faktörü ile açıklanabileceğini vurgulamaktadır. Bu doğrultuda $\mathrm{H}_{2}$ oluşturulmuştur.

\section{$\mathrm{H}_{2}:$ Mağazaya olan güvenin sadakat programı algısı üzerinde etkisi vardır.}

Ürün piyasasında müşteri ve işletmeler arasındaki ilişkinin kurulması işletme markaları tarafından sağlanmaktadır (Dall'Olmo Riley ve de Chernatony, 2000). Markaya duyulan sadakat algısı aynı zamanda tüketicilerin işletme ile ilişkilerinin kurulmasına katkı sağlamaktadır. Dolayısıyla marka sadakati ve ilişkiyi sürdürme isteği, ilişkisel pazarlama yaklaşımının birbirine bağlı besin zincirinin iki halkası olarak nitelendirilmektedir. İşletmeler tarafindan oluşturulacak sadakat programlarının fayda sağlaması, zincirin iki halkasının göz önüne alınarak yürütülmesi gerekmektedir (Fullerton, 2003; Sirdeshmukh vd., 2002). Bu doğrultuda $\mathrm{H}_{3}$ oluşturulmuştur.

\section{$H_{3}$ : Sadakat programı algısının ilişkiyi sürdürme isteği üzerinde etkisi vardır.}

\section{BULGULAR}

Çalışma kapsamında ilk olarak katılımcıların sayı ve yüzde frekans dağılımı verilmiştir. Tablo 3'de olduğu gibi katılımcıların; 113 kişisi $(\% 28,6)$ 25-34 yaş aralığında, 199 kişisi $(\% 50,4)$ erkek, 280 kişisi $(\% 70,9)$ evli, 155 kişisi $(\% 39,2)$ temizlik personeli, 124 kişisi $(\% 31,4)$ 3001-4000 aralı̆gnda aylık gelire sahip, 170 kişisi (\%43) 249-500 aralığında aylık mağaza harcama yapmaktadır. 125 kişisi $(\% 31,6)$ hanede 4 kişi yaşamaktadır, 213 kişisi $(\% 53,9)$ araç sahibidir, 182 kişisi $(\% 46,1)$ lisans mezunu ve 232 kişisi $(\% 58,7)$ kendi evi bulunmaktadır. 
Tablo 3: Katılımcı Demografik Bilgileri

\begin{tabular}{|c|c|c|c|}
\hline Demografik Bilgiler & Değişkenler & $\mathbf{n}$ & $\mathbf{f}(\%)$ \\
\hline \multirow{6}{*}{ Yaş } & 18-24 yaş & 48 & 12,2 \\
\hline & $25-34$ & 113 & 28,6 \\
\hline & $35-44$ & 105 & 26,6 \\
\hline & $45-54$ & 59 & 14,9 \\
\hline & $55-64$ yaş & 37 & 9,4 \\
\hline & 65 ve üstü & 33 & 8,4 \\
\hline \multirow{2}{*}{ Cinsiyet } & Erkek & 199 & 50,4 \\
\hline & Kadın & 193 & 48,9 \\
\hline \multirow{3}{*}{ Medeni Durumunuz } & Evli & 280 & 70,9 \\
\hline & Bekâr & 91 & 23,0 \\
\hline & Boşamış & 20 & 5,1 \\
\hline \multirow{7}{*}{ Meslek } & Öğretmen & 68 & 17,2 \\
\hline & Serbest meslek & 87 & 22,0 \\
\hline & Temizlik personeli & 155 & 39,2 \\
\hline & Avukat & 14 & 3,5 \\
\hline & İnşaat işçisi & 54 & 13,7 \\
\hline & Doktor & 15 & 3,8 \\
\hline & Fabrika işçisi & 2 & 0,5 \\
\hline \multirow{6}{*}{ Aylık Geliri } & 1000 TL ve alt 1 & 2 & 0,5 \\
\hline & $1001-2000 \mathrm{TL}$ & 80 & 20,3 \\
\hline & $2001-3000 \mathrm{TL}$ & 65 & 16,5 \\
\hline & $3001-4000 \mathrm{TL}$ & 124 & 31,4 \\
\hline & $4001-5000 \mathrm{TL}$ & 80 & 20,3 \\
\hline & 5001 ve üstü & 42 & 10,6 \\
\hline \multirow{6}{*}{ Aylık Harcama } & $0-249 \mathrm{TL}$ & 101 & 25,6 \\
\hline & $250-499 \mathrm{TL}$ & 170 & 43,0 \\
\hline & $500-749 \mathrm{TL}$ & 110 & 27,8 \\
\hline & $750-999 \mathrm{TL}$ & 3 & 0,8 \\
\hline & $1000-1499 \mathrm{TL}$ & 4 & 1,0 \\
\hline & 1500 TL ve üzeri & 1 & 0,3 \\
\hline \multirow{7}{*}{ Hanede Yaşayan Kişi Sayısı } & 1 Kişi & 13 & 3,3 \\
\hline & 2 Kişi & 43 & 10,9 \\
\hline & 3 Kişi & 96 & 24,3 \\
\hline & 4 Kişi & 125 & 31,6 \\
\hline & 5 Kişi & 89 & 22,5 \\
\hline & 6 Kişi & 24 & 6,1 \\
\hline & 7 Kişi ve üzeri & 4 & 1,0 \\
\hline \multirow{2}{*}{ Araç Sahipliği } & Evet & 213 & 53,9 \\
\hline & Hayır & 182 & 46,1 \\
\hline \multirow{7}{*}{ Eğitim } & Okur-yazar değil & 9 & 2,3 \\
\hline & İlkokul & 25 & 6,3 \\
\hline & Ortaokul & 25 & 6,3 \\
\hline & Lise & 93 & 23,5 \\
\hline & Ön Lisans & 37 & 9,4 \\
\hline & Lisans & 182 & 46,1 \\
\hline & Lisansüstü & 15 & 3,8 \\
\hline \multirow{4}{*}{ Ev Sahipliği } & Kira & 152 & 38,5 \\
\hline & Kendine ait & 232 & 58,7 \\
\hline & Lojman & 10 & 2,5 \\
\hline & Diğer & 1 & 0,3 \\
\hline
\end{tabular}

$\mathrm{n}=395$

Ölçek maddelerine uygulanan faktör analizi kapsamında 3 boyut elde edilmiştir. Boyutlar sadakat programı algısı, mağazaya olan güven ve ilişkiyi sürdürme isteği olarak belirlenmiştir. Faktör analizine göre faktör yükleri tablo 4’te verilmiştir. Verilerin faktör analizi kapsamında uygunluğu ve değişkenler arasındaki korelasyon katsayıları Barlett küresellik testi ve Kaiser-Mayer-Olkin (KMO) uygunluk ölçütü ile test edilmiştir. 
Tablo 4: Faktör Analizi Sonuçları

\begin{tabular}{|c|c|c|c|}
\hline Madde İfadeleri & $\begin{array}{l}\text { Faktör } \\
\text { yükleri }\end{array}$ & Varyans & Özdeğer \\
\hline \multicolumn{2}{|l|}{ ILLISSKIYYI SÜRDÜRME } & \multirow{11}{*}{28,446} & \multirow{11}{*}{7,680} \\
\hline Düzenli olarak bu mağazadan alış veriş yapıyorum & 676 & & \\
\hline Benim için bu mağaza market en iyi seçenektir & ,713 & & \\
\hline Uzun süredir bu mağazadan alışveriş yapıyorum & 627 & & \\
\hline $\begin{array}{l}\text { Bu mağazadan alışveriş yapan bir tüketici olarak daha kaliteli ürün ve hizmet için } \\
\text { daha fazla harcama yaparım }\end{array}$ & 441 & & \\
\hline Bu mağaza hakkında çevremdeki insanlara olumlu şeyler anlatırım & 618 & & \\
\hline Bu mağazayı başkalarına tavsiye ederim & 561 & & \\
\hline Bu mağazanın çalışanlarının sıcaklığı bana kendimi iyi hissettiriyor &, 576 & & \\
\hline Müşteri olarak kendimi bu mağazaya bağlı hissediyorum &, 578 & & \\
\hline Bu mağazanın bana sunduğu hizmetin her zaman aynı olacağından eminim &, 524 & & \\
\hline Bu mağaza güvenilir bir kuruluştur. & ,386 & & \\
\hline \multicolumn{2}{|l|}{$M A \breve{G} A Z A Y A G \ddot{U} V E N$} & \multirow{6}{*}{10,674} & \multirow{6}{*}{2,882} \\
\hline Bu mağaza da satılan ürünlerin kalitesine güveniyorum & ,738 & & \\
\hline $\begin{array}{l}\text { Bu mağaza da ürünlerin etiket fiyatıyla kasada ödediğim fiyat her zaman } \\
\text { birbiriyle tutarlıdır }\end{array}$ & ,706 & & \\
\hline Bu mağaza bana bir aidiyet duygusu vermiyor &, 508 & & \\
\hline $\begin{array}{l}\text { Başka seçenekler olmasına rağmen yine de bu mağazaya gelmekten } \\
\text { hoşlanıyorum }\end{array}$ &, 534 & & \\
\hline Evime yakın olduğu için bu mağazadan alış veriş yapıyorum &,- 339 & & \\
\hline \multicolumn{2}{|l|}{ SADAKAT PROGRAMI ALGISI } & \multirow{13}{*}{4,337} & \multirow{13}{*}{1,171} \\
\hline $\begin{array}{l}\mathrm{Bu} \text { mağazanın kartına ait kampanyalar, indirimler, promosyonlar, birikmiş } \\
\text { puanlar, çekilişler ve aktiviteler ile ilgili tanıtımlar yeterlidir }\end{array}$ & ,847 & & \\
\hline Bu mağazanın kartları içindeki süper ekranların kullanımı kolaydır & 649 & & \\
\hline Sadece indirimli ürünler için bu mağazadan alışveriş yapıyorum & 495 & & \\
\hline Bu mağazanın Kartı bütçeme önemli katkılar sağlamaktadır &, 427 & & \\
\hline $\begin{array}{l}\text { Bu mağazanın Kartı üyeleri için düzenlenen çekilişlerde cazip hediyeler } \\
\text { bulunmamaktadır }\end{array}$ &, 704 & & \\
\hline $\begin{array}{l}\text { Bu mağazanın Kartının sunduğu kişiye özel kampanyalar, promosyonlar ve } \\
\text { indirimler ihtiyaca yönelik değildir }\end{array}$ & ,748 & & \\
\hline Bu mağazanın Kartlarının mağazadaki alışverişlerin üzerinde etkisi yoktur & ,682 & & \\
\hline $\begin{array}{l}\text { Bu mağaza ile paylaştığım kişisel bilgilerin mağaza kartı aracılığı ile bana avantaj } \\
\text { olarak geri döneceğimi biliyorum }\end{array}$ & 482 & & \\
\hline $\begin{array}{l}\text { Bu mağaza da alışveriş sırasında herhangi bir problemle karşılaştı̆̆ım zaman } \\
\text { mağaza çalışanlarının yaklaşımını güven verici bulmuyorum }\end{array}$ &, 594 & & \\
\hline Bu mağazanın Kartının sunduğu fiyat indirimler pek çekici değildir & ,397 & & \\
\hline Bu mağazadan alışveriş yapmak bana zevk vermiyor &, 582 & & \\
\hline $\begin{array}{l}\text { Satılan ürünler aynı kalitede olduğu sürece başka bir mağazadan da alışveriş } \\
\text { yapabilirim }\end{array}$ &,- 391 & & \\
\hline \multicolumn{4}{|c|}{$\begin{array}{l}\text { Kaiser-Meyer-Olkin (KMO): ,905; Barlett Ki-Kare İstatistiği: 4640,249; Anlamlılık Değeri (p): 0,000 } \\
\text { Güvenilirlik Analizi: ,834; Toplam Varyans: 63;036; Çıkarım Yöntemi: Temel Bileşenler Analizi, } \\
\text { Döndürme Yöntemi: Varimax }\end{array}$} \\
\hline
\end{tabular}

Verilerin yorumlanmasında Kaiser Normalleştirmesi dikkate alınarak, özdeğeri 1'den büyük olan faktörler dikkate alınmıştır. Bu bağlamda oluşan 3 faktörün, toplam varyansı 63;036 açıklama özelliğine sahiptir. Ayrıca faktör yüklerinin $0,0,32$ 'den büyük olması analizin geçerli olabileceğini göstermektedir (Tabachnick ve Fidell, 1989).

Tablo 5: Değişkenler Arası Korelasyon Analizi Sonuçları

\begin{tabular}{llcrr}
\hline & & ílişkiyi Sürdürme & Mağazaya Güven & $\begin{array}{c}\text { Sadakat Programı } \\
\text { AlgıSı }\end{array}$ \\
\hline \multirow{2}{*}{ İlişkiyi Sürdürme } & Pearson Correlation & 1 &, 014 &, $408^{* *}$ \\
& Sig. (2-tailed) & &, 780 &, 000 \\
& $\mathrm{~N}$ & 395 & 395 & 395 \\
Mağazaya Güven & Pearson Correlation &, 014 & 1 &, 196 \\
\hline
\end{tabular}




\begin{tabular}{llccr}
\hline & Sig. (2-tailed) &, 780 &, 000 \\
& $\mathrm{~N}$ & 395 & 395 & 395 \\
Sadakat Program & Pearson Correlation &, $408^{* *}$ &, 196 & 1 \\
Algisı & Sig. (2-tailed) &, 000 &, 000 & 395 \\
& $\mathrm{~N}$ & 395 & 395 & 3 \\
\hline
\end{tabular}

$* * \mathrm{p}<0,01$

Tablo 5 de yer alan korelasyon sonuçları incelendiğinde değişkenler arasında; mağazaya güven ile sadakat programı ve sadakat programı algısı ile ilişkiyi sürdürme isteği arasında anlamlı $(p<0,01)$ ve beklenen ilişki olduğu görülmektedir. Dolayısıyla, ortaya çıkan anlamlı ilişki değişkenler arasındaki etkilerin incelenmesine imkân tanımaktadır. Bu bağlamda " $H_{1}$ : Mağazaya olan güvenin ilişkiyi sürdürme isteği üzerinde etkisi vardır." ve " $\mathrm{H}_{2}$ : Mă̆azaya olan güvenin sadakat programı algısı üzerinde etkisi vardır. ” Hipotezleri korelasyon analizi bulgularına göre (değişkenler arasında anlamlı bir ilişki olmadığı için) reddedilmiştir.

Tablo 6: Katılımcı Cinsiyet ve Araç Sahipliği T Testi

\begin{tabular}{lllll}
\hline Değişkenler & & Sadakat Programı AlgıS1 & Mağazaya Olan Güven & İlişkiyi Sürdürme İsteği \\
\hline Cinsiyet & Kadın & 2,404 &, 034 &, 041 \\
& Erkek & 2,317 &, 039 &, 044 \\
& Sig. &, 142 &, 902 &, $\mathbf{0 0 4}$ \\
Araç & Var & 2,290 &, 101 &, 108 \\
sahipliği & Yok & 2,439 &, 119 &, 126 \\
& Sig. & $\mathbf{, 0 0 2} *$ & $\mathbf{, 0 0 0} *$ &, 435 \\
\hline
\end{tabular}

Çalışma verilerinin basıklık (kurtosis) ve çarpıklık (skewness) değerleri göz önünde bulundurularak kontrolü sağlanmıştır. Elde edilen değerlerin $\% 5$ anlamlılık düzeyinde $+1,96$ ve $-1,96$ değerleri arasında olması normal dağılıma uygun olduğunu göstermektedir (Tabachnick ve Fidell, 2001). Araştırma da cinsiyet ve araç sahipliği değişkenlerine göre yapılan $t$ testi tablo 6'da verilmiştir. Tablo 6 incelendiğinde; cinsiyet değişkeninde ilişkiyi sürdürme boyutu ve araç sahipliği değişkeninde ise mağazaya olan güven ve sadakat programı algısı açısından anlamlı bir farklılık $(\mathrm{p}<0,05)$ olduğu görülmektedir. Erkek katılımcıların $(X=0,044)$ kadın katılımcılara $(X=0,041)$ göre ilişkiyi sürdürme düzeyinin daha yüksek olduğu görülmektedir. Araç sahipliği değişkenine göre aracı olmayanların $(X=2,439)$ olanlara $(X=2,290)$ göre sadakat programı algısının yüksek olduğu görülmektedir. Ayrıca, benzer şekilde araç sahipliği değişkeninde araç sahibi olmayanların $(X=0,119)$ olanlara $(X=0,101)$ göre mağazaya güven algısının yüksek olduğu görülmektedir.

Araştırmada; yaş, eğitim, aylık gelir, aylık harcama, ev sahipliği, hanede yaşayan kişi, ve medeni durum ile elde edilen boyutlar arasındaki ilişki durumunu belirlemek amacıyla tek yönlü varyans (ANOVA) analizi uygulanmıştır. Yapılan analizde farklılı̆̆ın kaynağını ölçmek amacıyla Post Hoc testlerinden Tukey testi kullanılmıştır. Grupların varyanslarının eşit olup olmadığını test etmek amacıyla Levene istatistiği uygulanmıştır. Bu analiz doğrultusunda $\mathrm{p}>0,05$ olduğu için eşit varyans varsayımına istinaden gruplar arasındaki farklılığın kaynağını görebilmek amacıyla Tukey testi kullanılmıştır.

Tablo 7: Katılımcı Yaş Anova Testi

\begin{tabular}{llll}
\hline YAŞ & Sadakat Programı Algısı & Mağazaya Olan Güven & İlişkiyi Sürdürme İsteği \\
\hline $\mathbf{1 8 - 2 4}$ yaş (a) & 2,296 &, 060 &, 181 \\
$\mathbf{2 5 - 3 4}$ yaş (b) & 2,261 &, 188 &, 059 \\
$\mathbf{3 5 - 4 4}$ yaş (c) & 2,332 &, 189 &, 240 \\
$\mathbf{4 5 - 5 4}$ yaş (d) & 2,367 &, 141 &, 039 \\
\hline
\end{tabular}




\begin{tabular}{llll}
\hline $\mathbf{5 5 - 6 4}$ yaș (e) & 2,423 &, 122 &, 107 \\
65 yaş ve üstü (f) & 2,786 &, 245 &, 514 \\
ANOVA & $\mathrm{F}=7,970$ & $\mathrm{~F}=2,954$ & $\mathrm{~F}=4,447$ \\
& $\mathrm{p}=, \mathbf{0 0 0 *}$ & $\mathrm{p}=, \mathbf{0 1 2}$ & $\mathrm{p}=, \mathbf{0 0 1 *}$ \\
\multirow{2}{*}{ Tukey } & $\mathbf{f}>\mathbf{b}$ & $\mathbf{c}>\mathbf{b}$ & $\mathbf{f}>\mathbf{b}$ \\
& $\mathbf{f}>\mathbf{c}$ & & $\mathbf{f} \mathbf{c}$ \\
\hline
\end{tabular}

Tablo 7 incelendiğinde, yaş değişkeni ile sadakat programı algısı, mağazaya olan güven ve ilişkiyi sürdürme isteği boyutları arasında anlamlı farklılıklar olduğu görülmektedir. Bu farklılığın hangi gruplar arasında olduğunu test etmek için Tukey testi yapılmıştır. Bu bağlamda analiz sonuçlarına göre; 65 yaş ve üstü katılımcıların (Ort.2,786) 25-34 yaş grubu (Ort.2,261) ve 35-44 yaş grubu (Ort.2,332) katılımcılara göre sadakat programı algısının daha yüksek olduğu görülmektedir. 35-44 yaş grubu katılımcıların (Ort.2,332) 25-34 yaş grubuna (Ort.2,261) göre mağazaya güven algısının daha yüksek olduğu görülmektedir. 65 yaş ve üstü katılımcıların (Ort.2,786) 25-34 yaş grubu (Ort.0,059) ve 35-44 yaş grubu (Ort. 0,240) katılımc1lara göre ilişkiyi sürdürme isteğinin daha yüksek olduğu görülmektedir.

Tablo 8: Katılımcı Eğitim Durumu Anova Testi

\begin{tabular}{llll}
\hline EĞİTiM & Sadakat Programı Algıs1 & Mağazaya Olan Güven & İlişkiyi Sürdürme İsteği \\
DURUMU & & & \\
\hline Ĕgitim Yok (a) & 2,574 &, 064 &, 618 \\
Illkokul (b) & 2,403 &, 207 &, 011 \\
Ortaokul (c) & 2,629 &, 304 &, 133 \\
Lise (d) & 2,520 &, 096 &, 057 \\
Ön lisans (e) & 2,258 &, 086 &, 106 \\
Lisans (f) & 2,216 &, 075 &, 122 \\
Lisansüstü (g) & 2,477 &, 084 &, 616 \\
ANOVA & $\mathrm{F}=8,109$ & $\mathrm{~F}=1,158$ & $\mathrm{~F}=2,749$ \\
& $\mathrm{p}=, \mathbf{0 0 0}$ & $\mathrm{p}=, 328$ & $\mathrm{p}=\mathbf{0 1 3}$ \\
Tukey & $\mathbf{g}>\mathbf{f}$ & & $\mathbf{g}>\mathbf{f}$ \\
\hline
\end{tabular}

Tablo 8'e göre katılımcıları eğitim durumuna göre anlamlı farklılıklar olduğu görülmektedir. Tablo 8 de görüldüğü üzere; eğitim durumu ile sadakat programı algısı ve ilişkiyi sürdürme isteği arasında anlamlı farklılık olduğu görülmektedir. Bu farklılığın hangi gruplar arasında olduğunu test etmek için Tukey testi yapılmıştır. Analiz sonuçlarına göre; eğitim durumu lisansüstü olan katılımcıların (Ort. 2,477) lisans katılımcılara (Ort. 2,216) göre sadakat programı algısının daha yüksek olduğu görülmektedir. Eğitim durumu lisansüstü olan katılımcıların (Ort. 0,616) lisans katılımcılara (Ort.0,122) göre ilişkiyi sürdürme isteğinin daha yüksek olduğu görülmektedir.

Katılımcıların gelir durumu incelendiğinde sadakat programı algısı ve ilişkiyi sürdürme boyutlarında anlamlı farklılıkların ortaya çıktığı görülmektedir. Bu amaçla tablo 9 incelendiğinde sadakat programı algısının aylık geliri 1001-2000 TL olan katılımcıların 1000 TL ve altı dışında kalan tüm gruplardan (Ort. 2,794) yüksek olduğu görülmektedir. Aynı zamanda ikili gruplar arasındaki anlamlı farklılık incelendiğinde ise aylık geliri 2001-3000 TL olanların (Ort.2,380) aylık geliri 3001-4000 TL olanlardan (Ort. 2,162) yüksek olduğu görülmektedir. İlişkiyi sürdürme isteği boyutunda gruplar arasındaki anlamlı farklılık ise aylık geliri 1001-2000 TL olanların (Ort. 0,562), 1000 TL ve altı dışında kalan tüm gruplardan (Ort. 0,244) dişında diğer tüm gruplardan yüksek olduğu görülmektedir. 
Tablo 9: Katılımcı Aylık Gelir Durumu Anova Testi

\begin{tabular}{|c|c|c|c|}
\hline GELİR DURUMU & Sadakat Programı Alg1sı & Mağazaya Olan Güven & İlişkiyi Sürdürme İsteği \\
\hline 1000 TL ve altı (a) & 2,416 & ,220 & 244 \\
\hline 1001-2000 TL (b) & 2,794 & 214 &, 562 \\
\hline 2001-3000 TL (c) & 2,380 & ,084 & ,113 \\
\hline $3001-4000$ TL (d) & 2,162 & ,068 & ,237 \\
\hline 4001-5000 TL (e) & 2,226 &, 117 &, 260 \\
\hline 5001 TL ve üstü (f) & 2,322 & ,148 & ,099 \\
\hline \multirow[t]{2}{*}{ ANOVA } & $\mathrm{F}=28,094$ & $F=1,698$ & $\mathrm{~F}=10,878$ \\
\hline & $\mathrm{p}=, \mathbf{0 0 0} *$ & $\mathrm{p}=, 134$ & $\mathrm{p}=, \mathbf{0 0 0} *$ \\
\hline \multirow[t]{5}{*}{ Tukey } & $b>c$ & & $\mathbf{b}>\mathbf{c}$ \\
\hline & b>d & & $b>d$ \\
\hline & b>e & & b>e \\
\hline & b>f & & $\mathbf{b}>\mathbf{f}$ \\
\hline & $c>d$ & & \\
\hline
\end{tabular}

Katılımcıların aylık harcama tutarları incelendiğinde tüm boyutlarda anlamlı farklılıkların olduğu görülmektedir. $\mathrm{Bu}$ amaçla tablo 10 incelendiğinde sadakat programı algısı açısından aylık market harcaması 0-249 TL olanların (Ort. 2,456) 500-749 TL olanlardan (Ort. 2,169) daha yüksek olduğu görülmektedir. Benzer şekilde aylık harcaması 250-499 TL (Ort. 2,413) 500-749 TL olanlardan (Ort. $2,169)$ daha yüksek olduğu görülmektedir. Mağazaya olan güven boyutunda aylık harcama tutarı 500749 TL olanların (Ort. 0,210) 0-249 TL olanlardan (Ort. 0,181) daha yüksek olduğu görülmektedir. İlişkiyi sürdürme isteği boyutunda anlamlı farklılı̆̆ın kaynağ ise şu şekildedir: aylık harcama tutarı 500749 TL olanların (Ort. -0,489) 0-249 TL (Ort. 0,227) ve 250-499 TL (Ort. 0,141) olanlara oranla daha yüksek olduğu görülmektedir.

Tablo 10: Katılımcı Aylık Harcama Anova Testi

\begin{tabular}{|c|c|c|c|}
\hline $\begin{array}{l}\text { AYLIK MARKET } \\
\text { HARCAMASI }\end{array}$ & Sadakat Programı Algısı & Mağazaya Olan Güven & İlişkiyi Sürdürme İsteğ \\
\hline $\begin{array}{l}\text { 0-249 TL (a) } \\
250-499 \text { TL (b) } \\
500-749 \text { TL (c) } \\
750-999 \text { TL (d) } \\
1000-1499 \text { TL (e) } \\
\text { 1500-2000 TL (f) } \\
\text { ANOVA }\end{array}$ & $\begin{array}{l}2,456 \\
2,413 \\
2,169 \\
1,910 \\
2,266 \\
2,456 \\
F=7,973 \\
p=000 *\end{array}$ & $\begin{array}{l}, 181 \\
, 017 \\
, 210 \\
, 853 \\
, 170 \\
, 181 \\
\mathrm{~F}=3,319 \\
\mathrm{n}=\mathbf{0 1 1} *\end{array}$ & $\begin{array}{l}, 227 \\
, 141 \\
, 489 \\
, 754 \\
, 425 \\
, 227 \\
\mathrm{~F}=13,239 \\
\mathrm{n}=000 *\end{array}$ \\
\hline Tukey & $\begin{array}{l}a>c \\
b>c\end{array}$ & c>a & $\begin{array}{l}\mathbf{c}>\mathbf{a} \\
\mathbf{c}>\mathbf{b}\end{array}$ \\
\hline
\end{tabular}

Katılımcıların yaşadıkları evlerin durumuna göre sadakat programı algıSı ve ilişkiyi sürdürme isteği boyutlarında anlamlı farklılık olduğu görülmektedir. Bu amaçla tablo 11'e göre, lojmanda yaşayanların (Ort. 2,755) evi kendisine ait (Ort. 2,348) ve kirada yaşayanlara (Ort. 2,347) göre daha yüksek olduğu görülmektedir. İlişkiyi sürdürme isteği boyutu ise benzer şekilde lojmanda yaşayanların (Ort. 0,690) evi kendisine ait (Ort. 0,020) ve kirada yaşayanlara (Ort. 0,019) göre daha yüksektir.

Tablo 11: Katılımeı Ev Sahipliği Anova Testi

\begin{tabular}{llll}
\hline EV SAHİPLIĞ̈̇ & Sadakat Programı Algıs1 & Mağazaya Olan Güven & İlişkiyi Sürdürme İsteği \\
& & & \\
\hline Kira (a) & 2,347 &, 021 &, 019 \\
Kendime ait (b) & 2,348 &, 025 &, 020 \\
Lojman (c) & 2,755 &, 240 &, 690 \\
ANOVA & $\mathrm{F}=4,401$ & $\mathrm{~F}=, 524$ & $\mathrm{~F}=3,366$ \\
& $\mathrm{p}=, \mathbf{0 1 3}$ & $\mathrm{p}=, 592$ & $\mathrm{p}=, \mathbf{0 3 6}$ \\
Tukey & $\mathbf{c}>\mathbf{a}$ & & $\mathbf{c}>\mathbf{a}$ \\
& $\mathbf{c}>\mathbf{b}$ & & $\mathbf{c}>\mathbf{b}$ \\
\hline
\end{tabular}


Katılımcıların aynı hanede yaşayan kişi sayısına göre, sadakat programı algısında anlamlı bir farklılık olduğu görülmektedir. Tablo 12 incelendiğinde aynı hanede 6 kişi yaşayanların (Ort. 2,576) 2 kişi yaşayanlardan (Ort. 2,185) sadakat programı algısının daha yüksek olduğu görülmektedir.

Tablo 12: Katılımcı Hanede Yaşayan Kişi Sayısı Anova Testi

\begin{tabular}{|c|c|c|c|}
\hline $\begin{array}{l}\text { HANEDE } \\
\text { YAŞAYAN } \\
\text { KIŞi் }\end{array}$ & Sadakat Programı Algısı & Mağazaya Olan Güven & İlişkiyi Sürdürme İsteği \\
\hline 1 Kişi (a) & 2,268 & ,023 & ,194 \\
\hline 2 Kişi (b) & 2,185 &, 020 & 069 \\
\hline 3 Kişi (c) & 2,291 &, 024 & ,130 \\
\hline 4 Kişi (d) & 2,392 &, 067 & 010 \\
\hline 5 Kişi (e) & 2,405 & ,078 &, 053 \\
\hline 6 Kişi (f) & 2,576 &, 113 &, 255 \\
\hline 7 Kişi (g) & 2,833 &, 352 & ,783 \\
\hline \multirow{2}{*}{ ANOVA } & $\mathrm{F}=3,554$ & $\mathrm{~F}=, 408$ & $\mathrm{~F}=1,366$ \\
\hline & $\mathrm{p}=, \mathbf{0 0 2} *$ & $\mathrm{p}=, 873$ & $\mathrm{p}=, 227$ \\
\hline Tukey & $\mathbf{f}>\mathbf{b}$ & & \\
\hline
\end{tabular}

Katılımcıların medeni durumları açısından sadakat programı algısı ve ilişkiyi sürdürme isteği boyutunda anlamlı bir farklılık olduğu sonucu ortaya çıkmıştır. Bu bağlamda tablo 13 incelendiğinde sadakat programı algısı, medeni durumu boşanmış/dul olanların (Ort. 2,658) evli (Ort. 2,365) ve bekâr (Ort. 2,282) olanlara oranla daha yüksek olduğu görülmektedir. Benzer şekilde ilişkiyi sürdürme isteği boyutunda da medeni durumu boşanmış/dul olanların (Ort. 0,711) evli (Ort.0,055) ve bekâr $($ Ort. 0,034) olanlara oranla daha yüksek olduğu görülmektedir.

Tablo 13: Katılımcı Medeni Durum Anova Testi

\begin{tabular}{llll}
\hline MEDENI & Sadakat Programı Algıs1 & Mağazaya Olan Güven & İlişkiyi Sürdürme İsteği \\
DURUM & & & \\
\hline Evli (a) & 2,365 &, 037 &, 055 \\
Bekar (b) & 2,282 &, 103 &, 034 \\
Boşanmış/Dul (c) & 2,658 &, 063 &, 711 \\
ANOVA & $\mathrm{F}=5,788$ & $\mathrm{~F}=, 885$ & $\mathrm{~F}=7,006$ \\
& $\mathrm{p}=, \mathbf{0 0 3} *$ & $\mathrm{p}=, 413$ & $\mathrm{p}=, \mathbf{0 0 1 *}$ \\
Tukey & $\mathbf{c}>\mathbf{a}$ & & $\mathbf{c}>\mathbf{a}$ \\
& $\mathbf{c}>\mathbf{b}$ & & $\mathbf{c}>\mathbf{b}$ \\
\hline
\end{tabular}

Sadakat programı algısında meydana gelen 1 puanlık artışın örgüte duyulan ilişkiyi sürdürme isteği üzerinde 0,812 puanlık bir artışa yol açtığı görülmektedir. Elde edilen $t$ değerinin her düzeyde anlamlılık göstermesi (Sig. $\left.=0,000^{*}\right)$ sadakat programı algısı değişkeninin istatistiksel olarak anlamlı bir katsayıya sahip olduğunu göstermektedir.

Tablo 14: İlişkiyi Sürdürme İsteği Sadakat Programı Algısı Regresyon Analizi

\begin{tabular}{|l|c|c|c|c|}
\hline & $\boldsymbol{R}^{\mathbf{2}}$ & $\boldsymbol{F}$ & $\boldsymbol{B}$ & $\boldsymbol{P}$ \\
\hline Model &, 167 & 78,625 & & \\
Sabit & & & $-1,915$ &, 000 \\
Sadakat Programı Algısı & & &, 812 &, 000 \\
\hline
\end{tabular}

Bağımlı Değişken: İlişkiyi Sürdürme İsteği 
Analiz bulgularında $\mathrm{R}^{2}$ değerine göre, sadakat programı algısı, ilişkiyi sürdürme isteğinin \%16,7'sini açıklamaktadır. Elde edilen bilgiler doğrultusunda " $H_{3}$ : Sadakat programı algısının ilişkiyi sürdürme isteği üzerinde etkisi vardır.” hipotezi kabul edilmiştir.

\section{SONUÇ}

Yirminci yüzyılın son dönemlerinde işletmeler yeni müşteri kazanmanın sadık müşterilere oranla daha maliyetli olduğu kanaatine varmıșlardır. Bu süreçte ortaya çıkan ilișkisel pazarlama modeli işletme bilimine yenilikler kazandırmıştır. Özellikle müşteriler ile yakın ilişkiler kurularak sadık müşteri profili oluşturma ve sürdürme eğilimi ön plana çıkmaktadır. Sürekli değişen müşteri beklenti ve istekleri karşısında müşteri-işletme ilişkisinin sürdürülebilir kılınması için müşterilere değer verildiğini gösterecek ek uygulamalara ihtiyaç duyulmuştur. Ayrıca işletmeler yoğun rekabet ortamında taklitten uzak bir model için müşterilerinin satın alma kararlarını takip etmek ve ona göre politika ve strateji üretmek amacıyla onların satın alma davranışlarını kayıt altına alacak bir uygulama zorunluluğunu doğurmuştur.

$\mathrm{Bu}$ uygulamalar literatürde uzun bir süre incelendikten sonra sadakat programları ismiyle anılmaya başlanmıştır. Sadık müşterilere verilen mikro çipli kartlar bu uygulamaların başında gelmektedir. Böylelikle sadakat kartları ile hem müşterilere mal ve hizmetin yanı sıra artı değer sağlamak hem de işletmelere sadık müşteri oluşturarak reklam maliyetini düşürmek ve müşterilerine yönelik etkili pazarlama stratejileri sağlanmasına firsat tanınmış olacaktır.

Mal ve hizmeti bir arada bulundurarak müşterilerine irili ufaklı birçok ürün satışı yapan perakendeci firmalar, her geçen gün hızla büyümektedir. Bu büyümenin yanı sıra perakendeci firmalar, yoğun rekabet şartlarına uyum sağlamak ve pazarda etkin konumda yer almak için müşterilerini elinde tutmak ve sürekli değişen beklenti ve isteklerine ayak uydurmak amacıyla sadakat kart uygulamaları yürütmektedir.

Araştırmaya katılan katılımcılardan erkeklerin kadın katılımcılara göre ilişkiyi sürdürme düzeyinin daha yüksek olduğu görülmektedir. Aracı olmayanların olanlara göre sadakat programı algısının yüksek olduğu görülmektedir. Yaş değişkenine göre, 65 yaş ve üstü yaş grubundaki katılımcıların diğer yaş gruplarındaki katılımcılara göre daha yüksek düzeyde ilişkiyi sürdürme isteğinde bulundukları tespit edilmiştir. Benzer şekilde, lisansüstü eğitime sahip katılımcıların diğer eğitim gruplarındaki katılımcılara göre ilişkiyi sürdürme istekleri daha yüksek düzeydedir. Hanede yaşayan kişi sayısı açısından sadakat programı algısında anlamlı bir farklılık vardır. Medeni durum açısından da sadakat programı algısı ve ilişkiyi sürdürme isteği açısından anlamlı bir farklılık bulunmaktadır. Dolayısıyla başarılı bir sadakat programı oluşturmak isteyen işletme yöneticilerinin bu farklılıkları gözeterek pazarlama stratejilerini belirlemeleri çok önemlidir. Keza, yapılan regresyon analizi de müşterilerin mağazaya karşı ilişkiyi sürdürme isteklerinin sadakat programını algıları tarafından anlamlı şekilde etkilendiğini göstermektedir. Çalışma, bu anlamda uygulama alanında yöneticilere katkı sunduğu gibi işletmelere rekabet üstünlüğü sağlayan sadakat programı algısını araştırması açısından teorik olarak müşteri sadakati konusuna katkı sağlamaktadır.

Bu bulgulara dayanarak, işletmelere sürekli şekilde müşteri istek ve beklentilerini takip etmeleri ve değişen durumlara uygun olarak kendilerini yenilemeleri, değişime adapte olmaları ve yenilikleri izlemeleri önerilebilir. Hatta işletme yöneticileri, Schumpeter'in değişmeyen tek şeyin değişimin kendisi olduğu ilkesini benimseyerek değişim ve yeniliklerin öncüsü olmaları gerektiğini bunun ise sadece müssteri odaklı üretim ve hizmetten geçtiğini unutmamalıdır.

Bu çalışmada Ankara'da bir perakende firmasının sadakat kart sahibi müş̧erileri üzerinde anket uygulanmıştır. Araştırmada elde edilen sonuçlar sadakat programının müşterileri tarafindan nasıl algılandığı, mağazaya olan güvenin ne ölçüde programa katkı sağladığı ve şüphesiz ilişkiyi sürdürme eğilimi arasındaki etkiler incelenmiştir. Elde edilen veriler güven faktörünün programın oluşmasında temel faktör olduğu ve ilişkiyi sürdürme eğilimini bu algı üzerine kurulduğunu görmek mümkündür. Mal ve hizmeti bir arada satan perakendeci kuruluşlar üzerinde yapılması her iki üründe de müşteriler ile kurulan sadakat bağının güven temelli olduğunun göstergesi olarak yorumlanabilmektedir. Taklidin daha kolay ve anlaşılması zor olan hizmet sektörlerine yönelik çalışmaların sadakat programlarının gelişimine katk1 sağlayacağı düşünülmektedir. Sadık müşteri oluşumunun, işletmenin reklam ve tutundurma 
faaliyetlerine katkı sağladığı düşünülmektedir. $\mathrm{Bu}$ bağlamda daha sonraki çalışmalarda sadık müşterilerin tutundurma faaliyetleri üzerine etkilerinin ölçülmesinin işletmelerin maliyetten kar sağlamaları açısından fayda sunacağı düşünülmektedir.

İleride yapılacak çalışmalarda sadakat kartı uygulamalarına ilişkin yeni modeller geliştirilerek işletmelerin rekabet güçleri artırılabilir. Aynı zamanda, mağazacılık alanında yapılan bu araştırmanın diğer hizmet sektörlerinde de uygulanarak karşılaştırmalı sonuçlara ulaşılması önerilmektedir.

\section{KAYNAKÇA}

Akın Acuner, Ş. (2004). Müsteri ilişsilerinde hareket noktası: Müsteri memnuniyeti ve ölçümü, 5. Baskı. Ankara: Milli Prodüktivite Merkezi Yayınları No: 655, Can Reklamevi Basım Yayın Ltd. Şti.,

Aktepe, C., Baş, M., Tolon, M. (2009). Müşteri ilişkileri yönetimi. Ankara:Detay Yayıncılık.

Alabay, M.N. (2008). Rekabet stratejisi olarak müşsteri ilişsiler yönetimi. Ankara: Gazi Üniversitesi Vakfi İktisadi İşletmeleri İlke Yayınevi.

Altıntaş, M. K. (2000). Tüketici davranışları: müşteri tatmininden müşteri değerine. İstanbul: Alfa Yayınları.

Altunışık, R., Özdemir, Ş., Torlak, Ö. (2012). Modern pazarlama. 5. Baskı. İstanbul: Değişim Yayınları.

Altunişik, R., Coşkun, R., Bayraktaroğlu, S., \& Yildirim, E. (2007). Sosyal bilimlerde araştırma yöntemleri. Sakarya: Sakarya Yayıncıl1k.

Amine, A. (1998). Consumers' true brand loyalty: The central role of commitment. Journal of Strategic Marketing, 6(4), 305-319.

Anderson, C. H. ve Vincze, J. W. (2004). Strategic marketing management. Second Edition. Boston/USA: Houghton Mifflin Company.

Aydın, O. (2014). Havayolu müşteri sadakat programlarının evrimi: Miles \& Smiles örneği. Yayımlanmamış yüksek lisans tezi, TC Maltepe Üniversitesi Sosyal Bilimler Enstitüsü İşletme Anabilim Dalı, İstanbul.

Ballester, D. E. ve Alemán, L. M. (2005). Marka güven, marka eşitliği için önemli midir? Ürün ve Marka Yönetimi Dergisi, 14(3), 187-196.

Baloglu, S. (2002). Dimensions of customer loyalty: Separating friends from well wishers. Cornell Hotel And Restaurant Administration Quarterly, 43(1), 47-59.

Berman, B. ve Evans, J. R. (2004). Retail management a strategic approach. Ninth Edition. New Jersey/U.S.A.: Pearson Prentice Hall.

Brennan, R., Bainess, P., Garneau, P. (2003). Contemporary strategic marketing. New York/U.S.A.: Palgrave Macmillan.

Bruhn, M. (2003). Relationship marketing managemet of customer relationship. London/England: Pearson Education Limited. 
Butscher, S. A. (2002). Customer clubs and loyalty programmes. Second Edition. Retrieved from https://ebookcentral.proquest.com/lib/gazi-ebooks/detail.action?docID=3002193, U.S.A on June 2, 2019.

Christopher, M., Payne, A., \& Ballantyne, D. (1991). Relationship marketing: bringing quality customer service and marketing together. Cranfied/United Kingdom: Marketing and logistics Group Cranfield School of Management, Cranfield Institue of Teknology.

Çabuk, S., Orel., F. \& Güler, E. (2006). Süpermarket müşterilerinin mağaza kartı tercih nedenlerine en fazla etki eden değişkenlerin ortaya çıarılmasına yönelik bir araştırma. Çukurova Üniversitesi Sosyal Bilimler Enstitüsü Dergisi, 15(2), 81-94.

Çakır, Yeygel Ç., S. ve Eğinli, Temel A. (2010). Memnun çalışanlar (Çalışan iliş̧kiler yönetimi/ERM) Memnun müşteriler (Müşteri ilişkileri yönetimi/CRM). Ankara: Detay Yayınc1lık.

Çatı, Kahraman, Koçoğlu, C. M., \& Gelibolu, L. (2010). Müşteri beklentileri ile müşteri sadakati arasındaki ilişki: beş yıldızlı bir otel örneği. Çukurova Üniversitesi Sosyal Bilimler Enstitüsü Dergisi, 19(1), 429-446.

Dall'olmo Riley, F. ve Chernatony, D. L. (2000). The service brand as relationships builder. British Journal of Management, 11(2), 137-150.

Demirel, Y. (2007) Müşteri ilişkileri yönetimi ve bilgi paylaşımı. 2. Baskı. İstanbul: IQ Kültür ve Sanat Yayıncilik.

Dick, A. S. ve Basu, K. (1994). Customer loyalty: toward an integrated conceptual framework. Journal of The Academy of Marketing Science, 22(Spring), 99-113.

Doyler, P. (2003). Değer temelli pazarlama: şirketinizi büyütmek ve hissedar değeri yaratmak için pazarlama stratejileri. (çev. Gülfidan Barış). İstanbul: Kapital Medya Hizmetleri A.Ş.

East, R., Hammond, K., Harris, P., \& Lomax, W. (2000). First-store loyalty and retention. Journal of Marketing Management, 16(4), 307-325.

Egan, J. (2004). Relationship marketing exploring relational strategies in marketing. Second Edition. London/England: Pearson Prentice Hall.

Erk, Ç. (2009). Müşteri için değer yaratma, müşteri sadakati oluşum süreci ve şirket performansina etkileri üzerine araştırma. Yayımlanmamış yüksek lisans tezi, Trakya Üniversitesi Sosyal Bilimler Enstitüsü, Edirne.

Erten, E. (2004) Perakendecilikte iliskisel pazarlama ve süpermarket sadakat kartları üzerine pilot bir araştırma. Yayımlanmamış yüksek lisans tezi, İstanbul Üniversitesi, İstanbul.

Fullerton, G. (2005), The impact of brand commitment on loyalty to retail service brands. Canadian Journal of Administrative Sciences, 22(2), 97-110.

Kılıç, S. ve Göksel, A. (2004). Tüketici davranışları: İndirim kartlarının tüketici satın alma karar süreci üzerindeki etkisine dair ampirik bir çalışma. Gazi Üniversitesi Íktisadi ve İdari Bilimler Fakültesi Dergisi, 6(2), 147-163.

Grönroos, C. (1997). Value-driven relational marketing: From products to resources and competencies. Journal of Marketing Management, 13(5), 407-419.

Ha, C. L. (1998). The theory of reasoned action applied to brand loyalty. Journal of Product \& Brand Management, 7(1), 51-61.

Hacıefendioğlu, Ş., \& Çolular, N. (2008). İlişkisel pazarlamada güven unsuru ve otel işletmelerinde uygulama. Kocaeli Üniversitesi Sosyal Bilimler Dergisi, (16), 107-126.

Hollensen, S. (2003). Marketing management: A relationship approach. London, UK: Pearson Education Limited.

İslamoğlu, A. H. (2006). Pazarlama yönetimi. 3. Baskı. İstanbul: Beta Basım Yayım A.Ş., 
Kalaycı, Ş. (2010). SPSS uygulamalı çok değişkenli istatistik teknikleri. Ankara: Asil Yayın Dağıtım.

Kılıç, N. (2010). İlişkisel pazarlamanın müşteri sadakati yaratmadaki etkisi: Bir hava yolu taşıma işletmesindeki uygulamanın incelenmesi. Yayımlanmamış yüksek lisans tezi, Dokuz Eylül Üniversitesi Sosyal Bilimler Enstitüsü İşletme Anabilim Dalı Pazarlama Programı, İzmir.

Knox, S. (1998). Loyalty-based segmentaion and the customer development process. European Management Journal, 16(6), 729-737.

Kotler, P. (2000). Pazarlama yönetimi. (çev. Nejat Muallimoğlu). İstanbul: Beta.

Kotler, P. ve Keller, K. L. (2006) Marketing management. Twelfth Edition. New Jersey/U.S.A.: Pearson Prentice Hall.

Kulabaş, Y., \& Sezgin, S. (2003). TORQUE-Müşteriyi geri döndürme kuvveti/Bir ilişkisel pazarlama modeli. ITUÜ Sosyal Bilimler Enstitüsü Dergisi, 2(5), 74-84.

Marina, S., Kartini, D., Sarı, D. ve Padmasasmita, S. (2016). Customer loyalty as the implications of price fairness determined by relationship marketing and service quality of airline services. South East Asia Journal of Contemporary Business, Economics and Law, 11(2).

MEGEP, (2008). Pazarlama ve perakende perakendeciliğin özellikleri. Ankara: T.C. Milli Eğitim Bakanlı̆̆1, $\quad 2 \quad$ Haziran $2019 \quad$ tarihinde http://hbogm.meb.gov.tr/modulerprogramlar/kursprogramlari/pazarlama/moduller/perakendecili k.pdf adresinden erişildi.

Morgan, R. M., \& Hunt, S. D. (1994). The commitment-trust theory of relationship marketing. Journal of marketing, 58(3), 20-38.

Oluç, M. (2006). Temel pazarlama kavramları. İstanbul: Beta Basım Yayım A.Ş.

Oyman, M. (2002). Müşteri sadakati sağlamada sadakat programlarının önemi. Kurgu Dergisi, Anadolu Üniversitesi, İletişim Bilimleri Fakültesi, Eskişehir.

Özdemir, M., \& Koçak, A. (2012). İlişkisel pazarlama çerçevesinde marka sadakatinin oluşumu ve bir model önerisi. Ankara Üniversitesi SBF Dergisi, 67(02), 127-156.

Pirinti, S. (2010). Güncel pazarlama yaklaşımlarından seçmeler. (İnci Varinli ve Kahraman Çatı, eds.), Değer Pazarlaması içinde. Ankara: Detay Yayıncılık.

Sirdeshmukh, D., Singh, J., \& Sabol, B. (2002). Consumer trust, value, and loyalty in relational exchanges. Journal of Marketing, 66(1), 15-37.

Styles, C., \& Ambler, T. (2003). The coexistence of transaction and relational marketing: Insights from the Chinese business context. Industrial Marketing Management, 32(8), 633-642.

Tabachnick, B. G. ve Fidell, L. S. (1989). Using multivariate statistics. Second Education. Northridge: California State University Publish.

Tabachnick, B. G. ve Fidell, L. S. (2001). Using multivariate statistics. Needham Heights: Mass. Ally and Bacon.

Türk Dil Kurumu. (2005). Türkçe sözlük. Ankara: TDK Yayınları.

Tek, Ö. B. (1997). Pazarlama ilkeleri Türkiye uygulamaları global yönetimsel yaklaşım. 7. Baskı. İstanbul: Cem Ofset Matbaacılık Sanayi A.Ş.

Tek, Ö. B., ve Özgül, E. (2005). Modern pazarlama ilkeleri. İzmir: Birleşik Matbaacıllk.

Too, L. H., Souchon, A. L., \& Thirkell, P. C. (2001). Relationship marketing and customer loyalty in a retail setting: a dyadic exploration. Journal of Marketing Management, 17(3-4), 287-319.

Ünal, O. (2013). Müşteri sadakat programları ve muhasebeleştirilmesi. Ankara: Sonçağ Yayıncıllk Matbaacılık Reklam San. Tic. Ltd. Şti. Gazi Kitabevi.

Varinli, İ. (2008). Pazarlamada yeni yaklaşımlar. 2. Baskı. Ankara: Detay Yayıncılık. 
Winer, R. S. (2007). Marketing management. Third Edition. New Jersey, USA: Pearson International Edition.

Yükselen, C. (2013). Pazarlama: İlkeler-yönetim-örnek olaylar. 10. Baskı. Ankara: Detay Yayıncılık. 